Jp.jok (Jurnal Pendidikan Jasmani, Olahraga dan Kesehatan)

http://ejurnal.budiutomomalang.ac.id/index.php/jpjok

Doi : $\underline{\text { https://doi.org/10.33503/jp.jok.v5i1.1722 }}$

\title{
Assessing Aspects Of Strength, Concentration, Interest, Physical Activity And Body Mass Index
}

\author{
Adi S ${ }^{1)}$, Rohmad Apriyanto ${ }^{2)}$, Made Bang Redy Utama ${ }^{3)}$, Rifqi Festiawan ${ }^{4)}$, \\ Guntur Firmans yah" ${ }^{5)}$, Yopi Hutomo Bhakti ${ }^{6}$ \\ ${ }^{1,2}$ Universitas Nahdlatul Ulama Sunan Giri Bojonegoro, Indonesia \\ ${ }^{3}$ Universitas Negeri Semarang, Indonesia \\ ${ }^{4}$ Universitas Jenderal Soedirman, Indonesia \\ ${ }^{5}$ Dinas Pendidikan Provinsi Jawa Timur SMA Negeri 1 Singosari, Indonesia \\ ${ }^{6}$ Pendidikan Olahraga, Universitas Muhammadiyah Kotabumi, Indonesia \\ Email: ${ }^{1}$ sajaadhie@gmail.com, ${ }^{2}$ rohmadapriyanto87@gmail.com ${ }^{3}$ bangredy1@gmail.com. \\ ${ }^{4}$ rifqi.festiawan@unsoed.ac.id, ${ }^{5}$ gunturpepeng@gmail.com, ${ }^{6}$ yopihutomobhakti@gmail.com
}

\section{ABSTRACT}

This study describes the strength, concentration, interest, physical activity and body mass index between regular schools and Islamic boarding schools based schools. The results of this study were carried out as material for evaluating the interests of interests. This research is a nonexperimental quantitative research. The sample in this study were high school students in regular schools and Islamic boarding schools in Kab. Bojonegoro. The number of regular students is 221, students of Islamic boarding schools are 245. The instruments used to measure the variables of this study include: the strength variable (Push Up, Sit Up, Back Up). Concentration variable using grid concentration test. Interest variables using a questionnaire. The physical activity variable used the international physical activity questionnaire (IPAQ short). The body mass index variable uses the national nutritional obesity formula. This research was conducted semi-online. Items of interest and physical activity were carried out offline, while physical fitness, concentration and body mass index were carried out boldly. Regular school excels at item strength and physical activity. Islamic boarding school-based schools are superior in concentration and interest. Regular schoolstudents tend to be obese than boarding schoolstudents.

Keywords: Strength, Concentration, Interests, Physical Activity, Body Mass Index

\section{Menilai Aspek Kekuatan, Konsentrasi, Minat, Aktivitas Fisik dan Indeks Massa Tubuh ABSTRAK}

Penelitian ini mendeskripsikan kekuatan, konsentrasi, minat, aktivitas fisik dan indeks massa tubuh antara sekolah reguler dan sekolah berbas is pondok pesantren. Hasil dari penelitian ini dilakukan sebagai bahan evaluasi pemangku kepentingan. Penelitian ini merupakan penelitian kuantitatif non eks perimen Sampel pada penelitian ini adalah sis wa SMA pada sekolah regular dan pondok pesantren Kab. Bojonegoro. Jumlah s is wa regular 221, sedangkan sis wa pondok pesantren 245. Instrumen yang digunakan untuk mengukur variabel penelitian ini antara lain: variabel kekuatan (Push Up, Sit Up, Back Up). Variabel Konsentrasi menggunakan grid concentration test. Varibel minat menggunakan angket. Variabel aktivitas fisik menggunakan kuesioner aktivitas fisik intemasional (IPAQ short). Variabel indeks massa tubuh menggunakan numus obesitas gizi nasional. Penelitian ini dilakukan dengan semi-daring. Item minat dan aktivitas fisik dilakukan luring, sedangkan kebugaran jasmani, konsentrasi dan indeks masa tubuh dilakukan daring. Sekolah reguler lebih unggul pada item kekuatan dan aktivitas fisik. Sekolah berbasis pondok pesantren lebih unggul dalam konsentrasi dan minat. Siswa sekolah reguler mempunyai kecenderungan menjadi gemuk daripada sis wapondok pesantren.

Kata Kunci: Kekuatan, Konsentrasi, Minat, Aktivitas Fisik, Indeks Massa Tubuh

Info Artikel

Dikirim

Diterima

Dipublikasikan
(C) 2021 IKIP BUDI UTOMO MALANG

P-ISSN 2613-9421

E-ISSN 2654-8003

\footnotetext{
Alamat korespondensi: sajaadhie@gmail.com

Universitas Nahdlatul Ulama Sunan Giri Bojonegoro, Jalan Jendral Ahmad Yani No.10, Jambean, Sukorejo, Kec. Bojonegoro, Kabupaten Bojonegoro, Jawa Timur 62115, Indonesia
} 


\section{PENDAHULUAN}

Strategi "lockdown" dan tinggal di rumah adalah upaya untuk mengendalikan pamdemi virus Covid (Sintema, 2020), sehingga aktivitas pembelajaran diarahkan menjadi E-learning membantu menfasilitasi pembe lajaran siswa (Subedi et al., 2020), siswa dengan kebutuhan khusus banyak berpartisipasi dalam pembelajaran e-learning (Basilaia \& Kvavadze, 2020). Elearning menjadi kebutuhan utama dalam pembelajaran masa pandemi.

Mata pelajaran pendidikan jasmani juga melaksanakan pe mbelajaran secara online. Namun, studi sebelumnya tentang efisiensi dan potensi kelas pendidikan jasmani online memiliki hasil terbatas (Lyu, 2011). Studi awal tentang dampak Covid19 menunjukkan penurunan tingkat aktivitas fisik anak-anak dan peningkatan tingkat obesitas anak-anak (An, 2020; Dunton et al., 2020). Dari hasil studi di atas dapat disimpulkan bahwa pembelajaran secara online mempunyai kecenderungan penurunan aktivitas fisik sehingga siswa mengalami obesitas.

Pendidikan jasmani dilaksanakan pada sekolah reguler yang berada pada naungan "Kemendikbud" dan pondok pesantren dalam naungan "Kemena g". Pada sekolah reguler, pendidikan jasmani dilaksanakan beriringan dengan ekstrakurikuler. Sedangkan perke mbangan pendidikan pondok pesantren saat ini sudah dilengkapi dasar dasar ilmu pengetahuan umum sebagai pelengkap kompetensi para santri. Santri adalah sebutan siswa pada sekolah berbasis pondok pesantren. Kekuatan, konsentrasi, minat, aktivitas fisik dan indeks massa tubuh merupakan variabel penting bagi siswa/santri karena padatnya aktivitas pembelajaran. Terlebih lagi pada santri yang harus seharian membaca Al-Quran, bahkan malam hari melaksanakan ibadah malam. Pada siswa reguler mumpunyai kegiatan tambahan les serta ekstrakurikuler. Jika kondisi beberapa variabel di atas lemah maka siswa/santri tidak bisa mengikuti semua kegiatan dengan baik. Disinilah perlunya pendidikan jasmani yang berperan terhadap performa siswa dalam pembelajaran secara keseluruhan khususnya dimasa pandemi.

Latihan kekuatan dapat digunakan untuk meningkatkan kebugaran secara keseluruhan, meningkatkan hipertrofi otot dan mengurangi kegemukan tubuh pada saat yang bersamaan. Faktanya, latihan kekuatan bisa menjadi cara yang efektif untuk memperbaiki komposisi tubuh (Paoli et al, 2010). Kekuatan juga 
diperlukan dalam kegiatan siswa sehari-hari seperti mengangkat tas, duduk, berdiri dan lain-lain. Konsentrasi diperlukan untuk daya tangkap siswa terhadap informasi yang masuk. Minat merupakan langkah awal ketertarikan siswa pada sesuatu. Aktivitas fisik dan indeks massa tubuh merupakan tolok ukur dalam menilai kecukupan gerak dan bentuk tubuh. Variabel diatas merupakan penentu keberhasilan siswa baik akademik maupun non akademik. Namun, penelitian terdahulu (Kusuma Wardani Soekardi \& Fakhruddin, 2017) hanya terbatas pada mendeskripsikan pelaksanaan pendidikan jasmani pondok pesantren.

Penelitian ini mendeskripsikan kekuatan, konsentrasi, minat, aktivitas fisik dan indeks massa tubuh antara sekolah reguler dan sekolah berbasis pondok pesantren. Beberapa variabel di atas dianggap sebagai variabel penting dalam aktivitas harian siswa. Hasil dari penelitian ini diharapkan dapat menjadi rekomendasi kebijakan pada pendidikan jasmani pada kedua subjek.

\section{METODE}

Peneltian ini menggunakan pendekatan kuantitatif non eksperimen untuk mendeskripsikan beberapa item kebugaran jasmani, konsentrasi, minat, aktivitas fisik dan indeks masa tubuh pada kedua kelompok sampel. Sampel pada penelitian ini adalah siswa SMA pada sekolah regular dan pondok pesantren setingkat SMA di Kab. Bojone goro. Jumlah siswa regular adalah 221, sedangkan jumlah siswa pondok pesantren adalah 245. Penelitian ini dilaksanakan pada bulan Agustus- November 2021. Item tes pada penelitian ini seperti Push Up, Sit Up, Back Up sebagai komponen kebugaran jasmani secara umum. Konsentrasi menggunakan grid concentration test diadopsi dari (Wienberg \& Gould. 2007). Minat adopsi angket (Supriyadi, 2007) dengan 30 butir pernyataan me liputi aspek sikap, keinginan, ketekunan dan dorongan. Aktivitas fisik dengan menggunakan angket bentuk pendek dari kuesioner aktivitas fisik internasional (IPAQ short) (Bassett, 2003). Indeks massa tubuh menggunakan rumus obesitas gizi nasional. Penelitian ini dilakukan dengan semi-daring. Item minat dan aktivitas fisik dilakukan luring, sedangkan kebugaran jasmani, konsentrasi dan indeks masa tubuh dilakukan daring. 
Grid Concentration Test yaitu sebuah tes konsentrasi dengan prosedur seorang mengurutkan angka secara runtut nilai terkecil 00 hingga terbesar 99 pada sebuah kolom kotak selama 1 menit. Semakin banyak siswa mengurutkan angka selama 1 menit, maka tingkat konsentrasi siswa dapat dikatakan semakin baik. Sebaliknya, semakin sedikit siswa mengurutkan angka dalam 1 menit, maka dapat dikatakan tingkat konsentrasi siswa tersebut juga semakin rendah. Siswa dikumpulkan di dalam kelas, diberikan lembar Grid Concentration test, didampingi satu orang tester untuk mengawasi jawaban benar atau salah.

Tingkat aktivitas fis ik menggunakan IPAQ short yang disebarkan melalui google form. Sebelum digunakan, kuesioner diterjemahkan terlebih dahulu. Indeks massa tubuh digunakan untuk menentukan apakah berat badan ideal, kurang, atau berlebih. Teknik analis is data menggunakan Uji Normalitas, Mean, Standar Deviasi, Min dan Max

\section{HASIL DAN PEMB AHASAN}

Tabel 1. Parameter Push Up

\begin{tabular}{clll}
\hline Skor & Kategori & Putra & Putri \\
\hline $\mathbf{5}$ & Sangat Tinggi & $>38$ & $>21$ \\
$\mathbf{4}$ & Tinggi & $29-37$ & $16-20$ \\
$\mathbf{3}$ & Sedang & $20-28$ & $10-15$ \\
$\mathbf{2}$ & Rendah & $12-19$ & $5-9$ \\
$\mathbf{1}$ & Sangat Rendah & $4-11$ & $1-4$ \\
\hline
\end{tabular}

Tabel 2. Parameter Sit Up

\begin{tabular}{clll}
\hline Skor & Kategori & Putra & Putri \\
\hline $\mathbf{5}$ & Sangat Tinggi & $>30$ & $>25$ \\
$\mathbf{4}$ & Tinggi & $26-30$ & $21-25$ \\
$\mathbf{3}$ & Sedang & $20-25$ & $15-20$ \\
$\mathbf{2}$ & Rendah & $17-19$ & $9-14$ \\
$\mathbf{1}$ & Sangat Rendah & $<17$ & $<9$ \\
\hline \multicolumn{4}{c}{} \\
\multicolumn{4}{|l}{ Tabel 3. Parameter Back Up } \\
\hline Skor & Kategori & Putra & Putri \\
\hline $\mathbf{5}$ & Sangat Tinggi & $>38$ & $>21$ \\
$\mathbf{4}$ & Tinggi & $29-37$ & $16-20$ \\
$\mathbf{3}$ & Sedang & $20-28$ & $10-15$ \\
$\mathbf{2}$ & Rendah & $12-19$ & $5-9$ \\
$\mathbf{1}$ & Sangat Rendah & $4-11$ & $1-4$ \\
\hline
\end{tabular}


Tabel 4. Parameter Aktifitas Fisik (Kowalski et al., 2004)

\begin{tabular}{cl}
\hline Skor & Kategori \\
\hline $\mathbf{5}$ & Sangat Tinggi \\
$\mathbf{4}$ & Tinggi \\
$\mathbf{3}$ & Sedang \\
$\mathbf{2}$ & Rendah \\
$\mathbf{1}$ & Sangat Rendah \\
\hline
\end{tabular}

Tabel 5. Indikator Obesitas Pedoman Gizi Nasional

\begin{tabular}{ll}
\hline Klasifikasi Status Gizi & IMT $\left(\mathbf{k g} / \mathbf{m}^{\mathbf{2}}\right)$ \\
\hline Sangat Kurus & $<17$ \\
Kurus Ringan & $17-18,4$ \\
Normal & $18,5-25,0$ \\
Gemuk Ringan & $25,1-27,0$ \\
Sangat Gemuk & $>30$ \\
\hline
\end{tabular}

\begin{tabular}{|c|c|}
\hline Skor & Kategori \\
\hline 21 Keatas & Sangat Baik \\
\hline $16-20$ & Baik \\
\hline 11-15 & Cukup \\
\hline 6-10 & Kurang \\
\hline 5 Kebawah & Sangat Kurang \\
\hline
\end{tabular}

\begin{tabular}{cl}
\hline & Tabel 7. Minat \\
\hline Skor & Kategori \\
\hline $\mathbf{5}$ & Sangat Tinggi \\
$\mathbf{4}$ & Tinggi \\
$\mathbf{3}$ & Sedang \\
$\mathbf{2}$ & Rendah \\
$\mathbf{1}$ & Sangat Rendah \\
\hline
\end{tabular}

Tabel 7. Hasil Uji Normalitas

\begin{tabular}{|c|c|c|c|c|}
\hline Jenis & Variabel & Sig & $\begin{array}{c}\text { Taraf } \\
\text { Signifikansi }\end{array}$ & Keterangan \\
\hline Sekolah & Push Up & 0,41 & \multirow{14}{*}{0,05} & Normal \\
\hline \multirow[t]{6}{*}{ Reguler } & Sit Up & 0,12 & & Normal \\
\hline & Back Up & 0,10 & & Normal \\
\hline & Konsentrasi & 0,12 & & Normal \\
\hline & Minat & 0,32 & & Normal \\
\hline & Aktivitas Fisik & 0,58 & & Normal \\
\hline & IMT & 0,51 & & Normal \\
\hline \multirow{7}{*}{$\begin{array}{l}\text { Pondok } \\
\text { Pesantren }\end{array}$} & Push Up & 0,19 & & Normal \\
\hline & Sit Up & 0.33 & & Normal \\
\hline & Back Up & 0,21 & & Normal \\
\hline & Konsentrasi & 0,42 & & Normal \\
\hline & Minat & 0,31 & & Normal \\
\hline & Aktivitas Fisik & 0,26 & & Normal \\
\hline & IMT & 0,36 & & Normal \\
\hline
\end{tabular}


Tabel 8. Deskripsi Data Penelitian

\begin{tabular}{|c|c|c|c|c|c|c|}
\hline Jenis & Item Tes & Mean & SD & Min & Max & Ket. \\
\hline Sekolah Reguler & \multirow[b]{2}{*}{ Push Up } & 23,09 & 8,73 & 10 & 42 & Sedang \\
\hline $\begin{array}{c}\text { Pondok } \\
\text { Pesantren } \\
\end{array}$ & & 20,5 & 9,95 & 8 & 39 & Sedang \\
\hline Sekolah Reguler & \multirow[b]{2}{*}{ Sit Up } & 26,1 & 7,22 & 13 & 45 & Tinggi \\
\hline $\begin{array}{c}\text { Pondok } \\
\text { Pesantren }\end{array}$ & & 22,6 & 8,77 & 10 & 41 & Sedang \\
\hline Sekolah Reguler & \multirow[b]{2}{*}{ Back Up } & 24,8 & 6,21 & 10 & 35 & Sedang \\
\hline $\begin{array}{c}\text { Pondok } \\
\text { Pesantren }\end{array}$ & & 19,6 & 8,21 & 7 & 32 & Rendah \\
\hline Sekolah Reguler & \multirow{2}{*}{ Konsentrasi } & 21,7 & 7,11 & 6 & 26 & $\begin{array}{l}\text { Sangat } \\
\text { Baik }\end{array}$ \\
\hline $\begin{array}{c}\text { Pondok } \\
\text { Pesantren }\end{array}$ & & 19,2 & 6,41 & 7 & 24 & Baik \\
\hline Sekolah Reguler & \multirow[b]{2}{*}{ Minat } & 3,21 & 6,10 & 2 & 5 & Sedang \\
\hline $\begin{array}{c}\text { Pondok } \\
\text { Pesantren }\end{array}$ & & 4,10 & 7,61 & 1 & 5 & Tinggi \\
\hline Sekolah Reguler & \multirow{2}{*}{$\begin{array}{l}\text { Aktivitas } \\
\text { Fisik }\end{array}$} & 3 & 5,2 & 2 & 5 & Sedang \\
\hline $\begin{array}{c}\text { Pondok } \\
\text { Pesantren }\end{array}$ & & 2 & 6,35 & 2 & 5 & Rendah \\
\hline Sekolah Reguler & \multirow{2}{*}{ IMT } & 26,9 & 9,3 & 18,9 & 32,8 & $\begin{array}{l}\text { Gemuk } \\
\text { Ringan }\end{array}$ \\
\hline $\begin{array}{c}\text { Pondok } \\
\text { Pesantren }\end{array}$ & & 23,1 & 8,10 & 18,0 & 29,1 & Normal \\
\hline
\end{tabular}

Pada item kekuatan yang dites menggunakan push-up, sit-up dan back up sekolah regular lebih unggul 23,09>20,5, 26,1>22,6, 24,8>19,6. Variabel data ini digunakan untuk mengukur item kekuatan siswa. Semakin banyak bukti yang muncul mendukung kebutuhan remaja usia sekolah untuk meningkatkan kekuatan otot mereka sehingga kinerja motorik mereka menjadi lebih baik (Artero et al., 2014; Hardy et al., 2012; Ortega et al., 2012). Kemampuan keterampilan motorik merupakan prediktor aktivitas fisik pada anak-anak dan remaja (Barnett et al., 2009; Lopes et al., 2011; Okely et al., 2001). Anak dengan keterampilan motorik yang lebih tinggi telah ditemukan mengungguli anak-anak dengan kompetensi motorik yang lebih rendah pada tes kebugaran fisik, perbedaan ini tampaknya tetap stabil dari waktu ke waktu (Fransen et al., 2014; Hands, 2008). Mengingat bahwa aktivitas fis ik menurun dengan cepat setelah pubertas (Whitt-Glover et al., 2009), program kebugaran yang secara khusus menargetkan defisit olahraga pada remaja usia sekolah harus dimulai sejak dini. Sekolah harus peduli terhadap 
156 Adi $\mathbf{S}^{1)}$, Rohmad Apriyanto ${ }^{2)}$, Made Bang Redy Utama ${ }^{3)}$, Rifqi Festiawan ${ }^{4)}$, Guntur Firmansyah ${ }^{\text {5) }}$, Yopi Hutomo Bhakti ${ }^{6}$.Jp.jok (Jurnal Pendidikan. Jasmani, Olahraga dan Kesehatan). 5(1) 150-164

peningkatan kebugaran jasmani melalui kekuatan. Kekuatan tangan diperlukan dalam seluruh aktivitas harian. Kekuatan punggung yang dites melalui back-up. Kekuatan otot punggung diperlukan dalam kegiatan duduk, membawa tas dan aktivitas lainnya. Otot perut digunakan seluruh aktivitas harian. Otot-otot kekuatan digunakan untuk mengangkat, mendorong, menarik, dan membawa (Peterson et al., 2019). Meskipun penelitian ini tidak membandingkan keterampilan antara anak-anak dengan kekuatan tinggi dan rendah. Anak dengan kekuatan otot rendah kurang terlibat dalam aktivitas fisik (Fransen et al., 2014; Haga, 2009; Hands, 2008).

Pada item konsentrasi siswa reguler lebih tinggi 21,7>19,2. Semakin tinggi konsentrasi siswa maka semakin baik pula dalam menghafal sesuatu. Menyadari bahwa tingkat konsentrasi siswa memiliki batas, guru dapat campur tangan untuk meminta tingkat konsentrasi yang lebih tinggi dengan berbagai tindakan aktif seperti latihan, pertanyaan, tugas khusus, atau kegiatan ke lompok yang membantu menghentikan rutinitas pembelajaran yang pasif. Penggunaan aktivitas pendidikan jasmani dapat mengembalikan konsentrasi. Pada tingkat cell, ditemukan bahwa latihan treadmill dapat meningkatkan neurogenes is hipokampus pada tikus tua (E et al., 2014). Menariknya, olahraga juga dapat mempengaruhi proliferasi (Li et al., 2005; Viola \& Loss, 2014), serta ukuran dan fungsi astrosit (Loprinzi, 2019). Peristiwa terakhir ini mengatur jumlah sinapsis neuron yang mempengaruhi konsentrasi dan pembentukan memori "episodik" (Chen \& Russo-Neustadt, 2009).

Minat pembelajaran pendidikan jasmani $4,10>3,21$ lebih tinggi pada pembe lajaran di sekolah reguler. Minat merupakan suatu kegiatan yang dilakukan oleh siswa secara tetap dalam melakukan proses belajar (Siagian, 2015). (Armi et al., 2015) menyatakan untuk mewujudkan suatu aktivitas olahraga perlu adanya minat karena dengan adanya minat akan menimbulkan rasa tertarik dansenang untuk melakukan aktivitas olahraga. Minat besar pengaruhnya terhadap belajar, karena bila bahan pelajaran yang dipe lajari tidak sesuai dengan minat siswa, siswa tidak akan belajar dengan sebaik-baiknya, karena tidak ada daya tarik baginya terhadap pelajaran tersebut. Semakin tinggi ketertarikan siswa dalam pembe lajaran pendidikan jas mani, semakin tinggi pula minatnya untuk melakukan 
aktivitas fisik. Beberapa hal yang mendasari minat adalah perasaan senang, ketertarikan siswa, perhatian dan keterlibatan siswa.

Aktivitas fisik siswa reguler lebih tinggi 3>2. Siswa reguler difasilitasi melalui ekstrakurikuler yang dilakukan di luar aktivitas pembelajaran. Sedangkan temuan pada pondok pesantren olahraga hanya dilakukan pada jam pembelajaran. Sehingga kecenderungan bergerak minim terutama pada siswa berjenis kelamin perempuan. Melakukan aktivitas fisik sederhana dapat digunakan untuk bertahan hidup (Cheng et al., 2018; Tiberi \& Piepoli, 2019). Jumlah waktu luang dan tidak melakukan aktivitas fisik memiliki korelasi negatif dengan risiko kematian kardiovaskular (Cheng et al., 2018). Kebugaran fisik tidak hanya mengurangi risiko kematian akibat penyakit kardiovaskular, tetapi juga mungkin dengan melakukan latihan fisik secara teratur (Engeseth et al., 2018). Aktivitas fisik yang terbatas atau, yang lebih mengkhawatirkan, ketidakmampuan untuk keluar rumah secara teratur akibat karantina yang ketat, dapat dikaitkan dengan risiko banyak gangguan dan penyakit seperti diabetes, kanker, osteoporosis, dan penyakit kardiovaskular (Castrogiovanni et al., 2016; Sanchis-Gomar et al., 2014). Penurunan aktivitas fisik juga dapat mempengaruhi kesehatan mental seseorang, yang dapat dialami sebagai emosi yang tidak menyenangkan seperti kesedihan, kemarahan dan frustrasi (Brooks et al., 2020).

Tingkat aktivitas fisik sangat berpengaruh terhadap kesehatan. Aktivitas fisik dengan tingkat sedang pada SMA, ketika menjadi mahasiswa beralih tidak aktif (Simona et al., 2015). Pendidikan jasmani memiliki keuntungan membuat gaya seseorang aktif yang meningkatkan aktivitas fisik. (Bailey et al., 2009). Meskipun hasil penelitian (Olivares et al., 2015) menyatakan pengaruh orang tua lebih penting daripada guru pendidikan jasmani untuk tetap menjaga aktivitas fisik

Indeks massa tubuh siswa reguler mempunyai kecenderungan menjadi gemuk 26,9>23,1. Namun pada pondok pesantren mempunyai kecenderungan menjadi kurus. Kurangnya aktivitas fisik menyebabkan tingkat kegemukan meningkat (Resnick et al., 2000). Tingkat aktivitas fisik yang tinggi berbanding terbalik dengan penyakit kardiovaskular, diabetes tipe 2 dan semua penyebab kematian terlepas dari penurunan berat badan (Swift et al., 2013). Waktu aktivitas 
158 Adi S $^{1)}$, Rohmad Apriyanto ${ }^{2)}$, Made Bang Redy Utama ${ }^{3)}$, Rifqi Festiawan ${ }^{4)}$, Guntur Firmansyah ${ }^{\text {5) }}$, Yopi Hutomo Bhakti ${ }^{6}$.Jp.jok (Jurnal Pendidikan. Jasmani, Olahraga dan Kesehatan). 5(1) 150-164

fisik yang disarankan untuk mencegah kenaikan berat badan lebih dari waktu yang disarankan untuk meningkatkan kesehatan (Hunter et al., 2010) melaporkan uji coba secara acak untuk mengevaluasi efek olahraga pada pemeliharaan penurunan berat badan.

Latihan aerobik (AE) ada lah intervensi populer untuk pengelolaan obesitas dan kelebihan berat badan. Beberapa ulasan dan meta-analisis tentang efek intervensi latihan aerobik pada penurunan berat badan telah diterbitkan. Dalam tinjauan sistematis dan meta-analisis baru-baru ini,(Thorogood et al., 2011). Latihan adalah sub-konsep dari aktivitas fisik ini dan termasuk dalam aktivitas fisik waktu luang dan didefinisikan sebagai aktivitas terstruktur yang direncanakan dan diulang (Caspersen et al., 1985). Kebanyakan individu obesitas tidak mempertahankan penurunan berat badan untuk waktu yang lama (Anderson et al., 2001; Wadden, 1993). Perubahan berat dipengaruhi oleh keseimbangan energi (Thomas et al., 2012). Jika pengeluaran energi tetap rendah, kenaikan berat badan akan terjadi.

Rerata hasil menunjukkan bahwa siswa regular memiliki nilai aktivitas fisik, push up, sit up maupun back up lebih baik dari siswa dari pondok pesentren. Namun demikian, pada saat bersamaan mereka juga memiliki nilai obesitas yang lebih tinggi. Penelitian ini terbatas pada aktivitas fisik. Penelitian ini tidak meneliti nutrisi yang masuk pada siswa. Kedepan, penelitian terkait nutrisi pada siswa menjadi rekomendasi penting bagi pemangku kepentingan. Dalam penelitian diatas sudah diketahui terkait dengan status gizi siswa. Status gizi adalah keadaan tubuh sebagai akibat dari konsumsi, penyerapan dan pemanfaatan makanan di dalam tubuh. Status gizi menunjukkan kondisi atau kondisi seseorangkarena penggunaan, penyerapan, dan penggunaan makanan (Naik et al., 2015). Akibat kurangnya asupan zat gizi dalam tubuh adalah malnutrisi. Malnutrisi adalah suatu kondisi yang disebabkan oleh konsumsi makanan bergizi buruk dan berbahaya tubuh (Chinyoka, 2014)

Penelitian yang dilakukan oleh Chinyoka terkait dengan gizi dan prestasi belajar (Chinyoka, 2014). Penelitian tersebut membuktikan bahwa siswa yang lapar dan kurang gizi dapat mempengaruhi banyak hal, seperti siswa tidak dapat melakukan pekerjaan fisik dan melakukan kegiatan olahraga dengan tulus, tidak 
dapat menghadiri kegiatan belajar sekolah, dan kehilangan konsentrasi saat mengikuti pembelajaran. Siswa yang tidak dapat mengikuti kegiatan pembelajaran dengan baik, maka mereka juga tidak akan dapat memahami pelajaran yang diberikan oleh guru, sehingga siswa tidak dapat mengerjakan tugas yang diberikan oleh guru, dan berdampak pada rendahnya prestasi belajar siswa.

Remaja membutuhkan zat gizi dalam jumlah yang relatif besar dibandingkan dengan anak-anak karena pada usia tersebut anak banyak melakukan aktivitas fisik. Aktivitas fisik dapat berjalan dengan baik jika tubuh mendapat asupan zat gizi yang cukup melalui makanan yang dikonsumsi karena asupan gizi diperlukan untuk meningkatkan energi selama aktivitas fisik. Gizi yang tepat dapat diperoleh dengan mengonsumsi makanan yang mengandung zat gizi yang dibutuhkan tubuh tetapi dalam jumlah yang sesuai dengan kebutuhan tubuh. Hal ini menunjukkan bahwa asupan gizi yang seimbang membuat tubuh menjadi sehat dan mengikuti proporsi tubuh antara tinggi dan berat badan. Namun jika kelebihan asupan yang masuk daripada energi yang dikeluarkan menyebabkan kegemukan. Anak dengan malnutrisi jangka panjang berdampak pada kejadian malnutrisi dan gangguan kognitif (Woodhouse \& Lamport, 2012) Jika terjadi gangguan kognitif, maka anak tidak akan-dapat fokus dan berkonsentrasi pada kegiatan belajar, sehingga berdampak pada prestasi belajar.

\section{SIMPULAN}

Sekolah reguler lebih unggul pada item kekuatan dan aktivitas fisik. Sekolah berbasis pondok pesantren lebih unggul dalam konsentrasi dan minat. Siswa sekolah reguler mempunyai kecenderungan menjadi gemuk daripada siswa pondok pesantren. Perlu adanya inovasi pembelajaran pada pendidikan jasmani di pondok pesantren melalui latihan kekuatan dan memperbanyak aktivitas fisik melalui ekstrakurikuler. Pada sekolah reguler perlu adanya inovasi yang menjadikan minat siswa menjadi meningkat serta olahraga yang meningkatkan konsentrasi. 
160 Adi $\mathbf{S}^{1}$, Rohmad Apriyanto ${ }^{2}$, Made Bang Redy Utama ${ }^{3)}$, Rifqi Festiawan ${ }^{4)}$, Guntur Firmansyah ${ }^{\text {) }}$, Yopi Hutomo Bhakti ${ }^{6}$.Jp.jok (Jurnal Pendidikan. Jasmani, Olahraga dan Kesehatan). 5(1) 150-164

\section{DAFTAR RUJUKAN}

An, R. (2020). Projecting the impact of the coronavirus disease-2019 pandemic on childhood obesity in the United States: A microsimulation model. Journal of Sport and Health Science, 9(4), 302-312. https://doi.org/https ://doi.org/10.1016/j.jshs.2020.05.006

Anderson, J. W., Konz, E. C., Frederich, R. C., \& Wood, C. L. (2001). Long-term weight-loss maintenance: a meta-analysis of US studies. The American Journal of Clinical Nutrition, 74(5), 579-584. https://doi.org/10.1093/ajen/74.5.579

Armi, D., Mansur, \& Nusufi, M. (2015). Partisipasi Orang Tua Terhadap Minat Anak Berolahraga Di Kecamatan Singkil Kabupaten Aceh Singkil. Jurnal Ilmiah Mahasiswa Pendidikan Jasmani, Kesehatan Dan Rekreasi Fakultas Keguruan Dan Ilmu Pendidikan Unsyiah, 1(November), 258-271.

Artero, E. G., España-Romero, V., Jiménez-Pavón, D., Martinez-Gómez, D., Warnberg, J., Gómez-Martínez, S., González-Gross, M., Vanhelst, J., Kafatos, A., Molnar, D., De Henauw, S., Moreno, L. A., Marcos, A., \& Castillo, M. J. (2014). Muscular fitness, fatness and inflammatory biomarkers in adolescents. Pediatric Obesity, 9(5), 391-400. https://doi.org/10.1111/j.2047-6310.2013.00186.x

Bailey, R., Richard, Armour, K., Kirk, D., Jess, M., Pickup, I., \& Sandford, R. (2009). The educational benefits claimed for physical education and school sport: An academic review. Research Papers in Education, 24. https://doi.org/10.1080/02671520701809817

Barnett, L. M., van Beurden, E., Morgan, P. J., Brooks, L. O., \& Beard, J. R. (2009). Childhood motor skill proficiency as a predictor of adolescent physical activity. The Journal of Adolescent Health: Official Publication of the Society for Adolescent Medicine, 44(3), 252-259. https://doi.org/10.1016/j.jadohealth.2008.07.004

Basilaia, G., \& Kvavadze, D. (2020). Transition to Online Education in Schools during a SARS-CoV-2 Coronavirus (COVID-19) Pandemic in Georgia. Pedagogical Research, 5, 1-9. https://doi.org/10.29333/pr/7937

Bassett, D. (2003). International physical activity questionnaire: 12-country reliability and validity. Medicine and Science in Sports and Exercise, 35, 1396. https://doi.org/10.1249/01.MSS.0000078923.96621.1D

Brooks, S., Webster, R., Smith, L., Woodland, L., Wessely, S., Greenberg, N., \& Rubin, G. (2020). The psychological impact of quarantine and how to reduce it: rapid review of the evidence. The Lancet, 395. https://doi.org/10.1016/S0140-6736(20)30460-8 
Caspersen, C. J., Powell, K. E., \& Christenson, G. M. (1985). Physical activity, exercise, and physical fitness: definitions and distinctions for health-related research. Public Health Reports (Washington, D.C. : 1974), 100(2), 126-131. https://pubmed.ncbi.nlm.nih.gov/3920711

Castrogiovanni, P., Trovato, F., Szychlinska, M., Nsir, H., Imbesi, R., \& Musumeci, G. (2016). The importance of physical activity in osteoporosis. From the molecular pathways to the clinical evidence. Histology and Histopathology, 31, 11793. https://doi. org/10.14670/HH-11-793

Chen, M. J., \& Russo-Neustadt, A. A. (2009). Running exercise-induced upregulation of hippocampal brain-derived neurotrophic factor is CREBdependent. Hippocampus, 19(10), 962-972. https://doi.org/10.1002/hipo.20579

Cheng, W., Zhang, Z., Cheng, W., Yang, C., Diao, L., \& Liu, W. (2018). Associations of leisure-time physical activity with cardiovascular mortality: A systematic review and meta-analys is of 44 prospective cohort studies. European Journal of Preventive Cardiology, 25(17), 1864-1872. https://doi.org/10.1177/2047487318795194

Chinyoka, K. (2014). Impact of Poor Nutrition on the Academic Performance of Grade Seven learners: A Case of Zimbabwe. International Journal of Learning and Development, 4, 73. https://doi.org/10.5296/ijld.v4i3.6169

Dunton, G. F., Do, B., \& Wang, S. D. (2020). Early effects of the COVID-19 pandemic on physical activity and sedentary behavior in children living in the U.S. BMC Public Health, 20(1), 1351. https://doi.org/10.1186/s12889020-09429-3

E, L., B urns, J., \& Swerdlow, R. (2014). Effect of high-intensity exerc ise on aged mouse brain mitochondria, neurogenesis, and inflammation. Neurobiology of Aging ,35. https://doi.org/10.1016/j.neurobiolaging.2014.05.033

Engeseth, K., Prestgaard, E., Mariampillai, J., Grundvold, I., Liestol, K., Kje ldsen, S., Bodegard, J., Erikssen, J., Gjesdal, K., \& Skretteberg, P. (2018). Physical fitness is a modifiable predictor of early cardiovascular death: A 35-year follow-up study of 2014 healthy middle-aged men. European Journal of Preventive Cardiology, $\quad 25, \quad 204748731879345$. https://doi.org/10.1177/2047487318793459

Fransen, J., Deprez, D., Pion, J., Tallir, I. B., D’Hondt, E., Vaeyens, R., Lenoir, M., \& Philippaerts, R. M. (2014). Changes in physical fitness and sports participation among children with different levels of motor competence: a 2year longitudinal study. Pediatric Exercise Science, 26(1), 11-21. https://doi.org/10.1123/pes.2013-0005

Haga, M. (2009). Physical fitness in children with high motor competence is 
different from that in children with low motor competence. Physical Therapy, 89(10), 1089-1097. https://doi.org/10.2522/ptj.20090052

Hands, B. (2008). Changes in motor skill and fitness measures among children with high and low motor competence: a five-year longitudinal study. Journal of Science and Medicine in Sport, 11(2), 155-162. https://doi.org/10.1016/j.jsams.2007.02.012

Hardy, L. L., Reinten-Reynolds, T., Espinel, P., Zask, A., \& Okely, A. D. (2012). Prevalence and correlates of low fundamental movement skill competency in children. Pediatrics, 130(2), e390-8. https://doi. org/10.1542/peds.2012-0345

Hunter, G. R., Brock, D. W., Byrne, N. M., Chandler-Laney, P. C., Del Corral, P., $\&$ Gower, B. A. (2010). Exercise training prevents regain of visceral fat for 1 year following weight loss. Obesity (Silver Spring, Md.), 18(4), 690-695. https://doi.org/10.1038/oby.2009.316

Kowalski, K., Crocker, P., Donen, R., \& Honours, B. (2004). The Physical Activity Questionnaire for Older Children (PAQ-C) and Adolescents (PAQA) Manual.

Kusuma Wardani Soekardi \& Fakhruddin. (2017). Kajian Pendidikan Jasmani Olahraga dan Kesehatan di Pondok Pesantren Askhabul Kahfi Kota Semarang. Journal of Physical Education and Sports, 6(1), 57-65. http://journal. unnes.ac.id/sju/index.php/jpes\%0AKajian

Li, J., Ding, Y.-H., Rafols, J., Lai, Q., Mcallister, J., \& Ding, Y. (2005). Increased astrocyte proliferation in rats after running exercise. Neuroscience Letters, 386, 160-164. https://doi.org/10.1016/j.neulet.2005.06.009

Lopes, V., Rodrigues, L., Maia, J., \& Malina, R. (2011). Motor coordination as predictor of physical activity in childhood. Scandinavian Journal of Medicine \& Science in Sports, 21, 663-669. https ://doi. org/10.1111/j.16000838.2009.01027.x

Loprinzi, P. (2019). The role of astrocytes on the effects of exercise on epis odic memory function. Physiology International, 106, 1-8. https://doi.org/10.1556/2060.106.2019.04

Lyu, M. (2011). A Case Study on Structure and Possibility of Online Courses in Physical Education. Journal of Research in Curriculum Instruction, 15, 353370.

Naik, S., Itagi, S., \& Patil, M. (2015). Relationship between nutrition status, intelligence and academic performance of Lambani school children of Bellary district, Karnataka. 3.54,5, 259-267.

Okely, A. D., Booth, M. L., \& Patterson, J. W. (2001). Relationship of physical activity to fundamental movement skills among adolescents. Medicine and 
Science in Sports and Exercise, 33(11), 1899-1904. https://doi.org/10.1097/00005768-200111000-00015

Olivares, P., Cossio-Bolaños, M., Gomez-Campos, R., Almonacid Fierro, A., \& García, J. (2015). Influence of parents and physical education teachers in adolescent physical activity. International Journal of Clinical and Health Psychology, 380. https://doi.org/10.1016/j.ijchp.2015.01.002

Ortega, F. B., Silventoinen, K., Tynelius, P., \& Rasmussen, F. (2012). Muscular strength in male adolescents and premature death: cohort study of one million participants. BMJ,345. https://doi.org/10.1136/bmj.e7279

Paoli, A., Pacelli, F., Bargossi, A. M., Marcolin, G., Guzzinati, S., Neri, M., Bianco, A., \& Palma, A. (2010). Effects of three distinct protocols of fitness training on body composition, strength and blood lactate. The Journal of Sports Medicine and Physical Fitness, 50(1), 43-51.

Peterson, D., Middleton, M., Corresponding, C., \& Peterson, D. (2019). Evaluation of Possible Anthropometric Advantage in Sit-Up Test.

Resnick, H. E., Valsania, P., Halter, J. B., \& Lin, X. (2000). Relation of weight gain and weight loss on subsequent diabetes risk in overweight adults. Journal of Epidemiology I\& Community Health, 54(8), 596-602. https://doi.org/10.1136/jech.54.8.596

Sanchis-Gomar, F., Lucia, A., Yvert, T., Ruiz-Casado, A., Pareja-Galeano, H., Santos-Lozano, A., Fiuza-Luces, C., Garatachea, N., Lippi, G., Bouchard, C., \& Berger, N. (2014). Physical Inactivity And Low Fitness Deserve More Attention To Alter Cancer Risk And Prognosis. Cancer Prevention Research, 8. https://doi.org/10.1158/1940-6207.CAPR-14-0320

Siagian, R. (2015). Pengaruh Minat dan Kebiasaan Belajar Siswa terhadap Prestasi Belajar Matematika. Formatif: Jurnal Ilmiah Pendidikan MIPA, 2. https://doi.org/10.30998/formatif. v2i2.93

Simona, F., Radu, L., \& Vanvu, G. I. (2015). The Level of Physical Activity of University Students. Procedia - Social and Behavioral Sciences, 197, 14541457. https://doi.org/10.1016/j.sbs pro.2015.07.094

Sintema, E. J. (2020). Effect of COVID-19 on the Performance of Grade 12 Students: Implications for STEM Education. Eurasia Journal of Mathematics, Science and Technology Education, 16. https://doi.org/10.29333/ejmste/7893

Subedi, S., Nayaju, S., Subedi, S., Shah, S. K., \& Shah, J. M. (2020). Impact of Elearning during COVID-19 Pandemic among Nursing Students and Teachers of Nepal. International Journal of Science and Healthcare Research (Www.Ijshr.Com), 5(3), 68. www.ijshr.com 
Swift, D. L., Lavie, C. J., Johannsen, N. M., Arena, R., Earnest, C. P., O’Keefe, J. H., Milani, R. V, Blair, S. N., \& Church, T. S. (2013). Physical activity, cardiorespiratory fitness, and exercise training in primary and secondary coronary prevention. Circulation Journal : Official Journal of the Japanese Circulation Society, 77(2), 281-292. https://doi.org/10. 1253/circj.cj-13-0007

Thomas, D. M., Bouchard, C., Church, T., Slentz, C., Kraus, W. E., Redman, L. M., Martin, C. K., Silva, A. M., Vossen, M., Westerterp, K., \& Heymsfield, S. B. (2012). Why do individuals not lose more weight from an exercise intervention at a defined dose? An energy balance analysis. Obesity Reviews : An Official Journal of the International Association for the Study of Obesity, 13(10), 835-847. https://doi. org/10.1111/j. 1467789X.2012.01012.x

Thorogood, A., Mottillo, S., Shimony, A., Filion, K. B., Joseph, L., Genest, J., Pilote, L., Poirier, P., Schiffrin, E. L., \& Eisenberg, M. J. (2011). Isolated aerobic exercise and weight loss: a systematic review and meta-analysis of randomized controlled trials. The American Journal of Medicine, 124(8), 747-755. https://doi.org/10.1016/j.amjmed.2011.02.037

Tiberi, M., \& Piepoli, M. F. (2019). Regular physical activity only associated with low sedentary time increases survival in post myocardial infarction patient. European Journal of Preventive Cardiology, 26(1), 94-96. https://doi.org/10.1177/2047487318811180

Viola, G. G., \& Loss, C. M. (2014). Letter to Editor about: "Physical exerc ise increases GFAP expression and induces morphological changes in hippocampal astrocytes". In Brain structure \& function (Vol. 219, Issue 4, pp. 1509-1510). https://doi. org/10.1007/s00429-013-0563-1

Wadden, T. A. (1993). Treatment of obesity by moderate and severe caloric restriction. Results of clinical research trials. Annals of Internal Medicine, $119(7$ Pt 2), 688-693. https://doi.org/10.7326/0003-4819-119-7_part_2199310011-00012

Whitt-Glover, M. C., Taylor, W. C., Floyd, M. F., Yore, M. M., Yancey, A. K., \& Matthews, C. E. (2009). Disparities in physical activity and sedentary behaviors among US children and adolescents: prevalence, correlates, and intervention implications. Journal of Public Health Policy, 30 Suppl 1, S30934. https://doi.org/10.1057/jphp.2008.46

Woodhouse, A., \& Lamport, M. A. (2012). The Relationship of Food and Academic Performance: A Preliminary Examination of the Factors of Nutritional Neuroscience, Malnutrition, and Diet Adequacy. 